DATA DE

RECEPCIÓN:

20/05/2019

\section{DATA DE}

ACEPTACIÓN:

$10 / 12 / 2019$

\section{ECOS DE ALICE E LEWIS CARROLL EM VIRGÍNIA DE CASTRO ALMEIDA E} MANUEL ANTÓNIO PINA

\author{
ECOS DE ALICE Y LEWIS CARROLL EN VIRGÍNIA DE CASTRO ALMEIDA Y \\ MANUEL ANTONIO PINA
}

\section{ECHOS OF ALICE AND OF LEWIS CARROLL IN VIRGÍNIA DE CASTRO E ALMEIDA E MANUEL ANTÓNIO PINA}

\author{
Sara Reis da Silva \\ Instituto de Educação - Universidade do Minho \\ CIEC - Centro de Investigação em Estudos da Criança \\ sarasilva@,ie.uminho.pt
}

Resumo: Pretende-se, com este estudo, analisar algumas das manifestações intertextuais de raiz carrolliana na produção literária de dois importantes autores da literatura portuguesa para a infância e a juventude: Virgínia de Castro e Almeida (1878-1945) e Manuel António Pina (1943-2012). Situados em épocas e estéticas distantes, os textos de ambos reflectem a "sombra tutelar" de Aventuras de Alice no País das Maravilhas (1985) ou, genericamente, do mundo literário de Lewis Carroll (1832-1898). De obras como Aventuras de Dona Redonda e da Sua Gente (1942), de Virgínia de Castro e Almeida, ou Gigões \& Anantes (1974), de Manuel António Pina, ressumam traços singulares como o nonsense, o absurdo, o tópico do mundo às avessas e o humor, bem como o uso original do paradoxo, da metáfora e do jogo de sentidos, entre outros, características sobre as quais centraremos a nossa atenção e que atestam a pervivência do legado carrolliano na literatura portuguesa.

Palavras-chave: Aventuras de Alice no País das Maravilhas; Lewis Carroll; Virgínia de Castro e Almeida; Manuel António Pina; Intertextualidade.

Resumen: Se pretende con este estudio analizar algunas de las manifestaciones intertextuales de raíz carrolliana en la producción literaria de dos autores importantes de la literatura portuguesa para niños y jóvenes: Virginia de Castro e Almeida (1878-1945) y Manuel António Pina (1943- 2012). Situados en épocas y estéticas distantes, los textos de ambos reflejan la "sombra tutelar" de Aventuras de Alicia en el País de las Maravillas (1985) o, genéricamente, del mundo literario de Lewis Carroll (1832-1898). Obras como Aventuras de Dona Redonda e da Sua Gente (1942), de Virginia de Castro e Almeida, o Gigões \& Anantes (1974), de Manuel António Pina, muestran rasgos singulares como el nonsense, el absurdo, el tópico del mundo al revés y el humor, así como el uso original de la paradoja, la metáfora y juegos de sentidos, entre otras características en las que nos centraremos y que atestiguan la pervivencia de la herencia carrolliana en la literatura portuguesa.

Palabras clave: Aventuras de Alicia en el país de las maravillas; Lewis Carroll; Virgínia de Castro e Almeida; Manuel António Pina; Intertextualidad.

Abstract: The purpose of this study is to analyze some of the intertextual manifestations of Carrollian roots in the literary texts of two important authors of Portuguese Children's and youth literature: Virgínia de Castro e Almeida (1878-1945) e Manuel António Pina (1943-2012). Set in distant times and aesthetics, their texts reflect the "tutelary shadow" of Alice's Adventures in Wonderland (1985) or, generally, the literary world of Lewis Carroll (18321898). From works such as Aventuras de Dona Redonda e da Sua Gente (1942) by Virgínia de Castro e Almeida, or Gigões \& Anantes (1974) by Manuel António Pina, stand out traits such as nonsense, absurdity, humor, the world upside down, as well as the original use of paradox, metaphors or puns, among others, characteristics on which we will focus our attention and that attest the durability of the carrolliano legacy in the Portuguese Literature.

Keywords: Alice's Adventures in Wonderland; Lewis Carroll; Virgínia de Castro e Almeida; Manuel António Pina; Intertextuality. 


\section{Sara Reis da Silva}

"Alice é única. Não existe nenhuma personagem da História da Literatura que lhe chegue aos calcanhares. É a primeira heroína criança. É engraçada. É curiosa. É valente. É emotiva. Tem um apurado sentido de Justiça. É esperta. É sentimental. É lógica. É rapariga.»

(Vasconcelos, 2009: 112).

\section{Introdução': ressonâncias carrollianas ${ }^{2}$}

Aquilo que a teoria da literatura tem vindo a equacionar como «memória do sistema semiótico literário» (Silva, 1990: 628), no qual coexistem «elementos de natureza meta-histórica [...], elementos de ordem lógico-semântica [...] e elementos de natureza histórica» (Silva, 1990: 261), esse «influxo» (Silva, 1990: 261) ao qual o emissor não pode furtar-se, na medida em que todo o texto se situa «numa constelação precedente de textos» (Stierle, 2008: 41), ou, em concreto, se distingue pela sua dimensão potencialmente intertextual (Bakhtine, 1984; Kristeva, 1974; Barthes, 1984; Rifaterre, 1979) corporiza-se na própria história da recepção do clássico As Aventuras de Alice no País das Maravilhas (1865). Estudos distintos têm atestado a relevância da escrita de Lewis Carroll (C. L. Dodgson) (1832-1898) como matriz criativa da produção literária ${ }^{3}$ de autores de diferentes nacionalidades, estabelecendo esta obra um precedente nos livros para a infância, além de ser entendida como um ponto de viragem na literatura inglesa para crianças ${ }^{4}$.

Multiplicam-se, pois, as alusões à "sombra" tutelar deste autor e desta obra, muito especialmente, de Alice - essa figura tida como «uma das personagens mais míticas de todos os tempos» (Vasconcelos, 2009: 112) -, na escrita de outros. Veja-se, apenas, dois exemplos de outras latitudes: o do poeta brasileiro Paulo Mendes Campos (1922-1991) que, como regista Ana Maria Machado, em Como e Por Que Ler os Clássicos Universais desde Cedo, «celebrou Alice no País das Maravilhas, do inglês Lewis Carroll, como uma das chaves que abrem as portas da realidade» (Machado, 2002: 10); e o do norueguês Jostein Gaarder, o autor do amplamente divulgado $O$ Mundo de Sofia, obra que motiva a Haral Bache-Wigg o seguinte comentário:

\footnotetext{
${ }^{1}$ Por vontade expressa da sua autora, este texto encontra-se escrito segundo a antiga norma ortográfica da língua portuguesa.

2 Este estudo resultou das múltiplas pesquisas efectuadas durante a concretização da nossa dissertação de doutoramento intitulada Presença e Significado de Manuel António Pina na Literatura Portuguesa para a Infância e a Juventude (FCT/FCG, 2013).

${ }^{3} \mathrm{Na}$ verdade, esta "herança" não é apenas literária. Como preconiza Lerer, «El legado de Carroll, de Lear y de sus herederos se esconde en la anárquica indústria de lo lúdico propia del movimento dadaísta. Los poetas, los pintores y los artistas de teatro de las primeras décadas del siglo XX hicieron de lo absurdo la estética determinante de ese siglo.» (Lerer, 2009: 319)

${ }^{4}$ Zohar Shavit enfatiza que «algumas histórias nem sequer hesitam em dividir toda a história da literatura para crianças inglesa em «antes de Alice»e «depois de Alice» (ver Muir, 1969).» (Shavit, 2003: 110).
} 


\title{
Ecos de Alice e Lewis Carroll em Virgínia de Castro Almeida e Manuel António Pina
}

\begin{abstract}
Gaarder's rabbit metaphor is clearly drawing on the world's most famous children's book with a philosophical content, Lewis Carroll's Alice in Wonderland. The rabbit in Carroll's book never rests, but always runs on in an unstable, steadily altered world, anxious to avoid being late for the garden party at the Queen's, which turns out to be just as chaotic as the garden party in Sophie's World. (Bache-Wiig, 2006: 272).
\end{abstract}

De igual modo, no âmbito da literatura portuguesa, independentemente do seu preferencial receptor, as ressonâncias carrollianas são plurais e plasmam-se diversamente, apresentando-se umas relativamente subtis - como parece suceder com As Meninas de La Mancha (Asa, 1990), de Sara H. Monteiro, e A Verdadeira História de Alice (Caminho, 2004), de Rita Taborda Duarte $^{5}$-, outras francamente impressivas como atesta a mais recente novela dada à estampa por Mário Cláudio, O Fotógrafo e a Rapariga (D. Quixote, 2015). Não surpreende, na verdade, visto que, mesmo não se observando nenhuma informação referente à publicação em Portugal de qualquer texto da autoria de Carroll antes de 1928, como regista Gomes (1999), o facto é que se afigura perfeitamente provável e/ou plausível que o seu nome fosse já conhecido nos meios literários portugueses no dealbar do século XX.

$\mathrm{Na}$ História desta literatura portuguesa que tem na criança e no jovem o seu potencial destinatário ${ }^{6}$, não será difícil constatar a singularidade da influência em discussão em dois autores fundamentais aos quais dedicaremos, daqui em diante, uma atenção mais demorada. Ainda que distintamente situados, tanto topologica como cronologicamente, em ambos, a incidência carrolliana revela-se estruturante, sendo, aliás, abertamente confessada. Referimo-nos, em concreto, a Virgínia de Castro e Almeida (1874-1945) e Manuel António Pina (1943-2012), cuja escrita revisitaremos, de seguida, no contexto temático em pauta.

\footnotetext{
${ }^{5}$ Correspondendo estas duas narrativas às obras de estreia das autoras em questão, possuem também em comum o facto de ambas terem sido premiadas: a primeira com o prémio Inasset-Inapa do Centro Nacional de Cultura e a segunda com o Prémio Branquinho da Fonseca Expresso/Gulbenkian.

${ }^{6}$ Importa talvez ter em conta que, no domínio da edição vocacionada para os leitores mais novos, a tradução e adaptação de Aventuras de Alice no País das Maravilhas se revestiu de particular importância merecendo a atenção de alguns nomes importantes do universo em causa. Tenham-se em conta, por exemplo, os casos dos volumes Alice no País das Maravilhas, assinado por Henrique Marques Júnior, na edição de 1942, com desenhos de Amorim e, na de 1951, com ilustrações de René Bour (Romano Torres, 1942/1951); Aventuras de Alice no País das Maravilhas, traduzido do inglês por Maria de Meneses (Portugália Editora, 1943). Já na década de 60 do século XX, com as chancelas da Portugália Editora e da Editorial Verbo, vieram também a lume duas traduções da obra, uma de Maria de Meneses (1966) e outra de Maria das Mercês Mendonça Soares (1967), respectivamente, conforme disso dá notícia o catálogo A Literatura Infantil em Portugal, de Domingos Guimarães de Sá (Editorial Franciscana, 1981).
} 


\section{Sara Reis da Silva}

\section{Virgínia de Castro e Almeida e o seu «ensaio de humour ao alcance das crianças latinas»}

Um breve apontamento inicial para reafirmar o relevante lugar ocupado por Virgínia de Castro e Almeida na literatura portuguesa para a infância e a juventude. Merecedora de referência em todos os estudos historiográficos levados a cabo até à data, a saber por Lemos (1972), Pires (1983), Rocha (1984/2001) e Gomes (1997), Virgínia de Castro e Almeida, atravessando três regimes (a Monarquia, a República e o Estado Novo), foi uma autora prolífica - além de tradutora, por exemplo -, tendo repartido a sua actividade pelo ensaio, muitas vezes de carácter pedagógico e doutrinário, pelos argumentos cinematográficos, pelo romance, pelas impressões de viagens, pelos textos em torno da História ${ }^{7}$ e de figuras históricas ${ }^{8}$ e pela literatura infantil, acervo inaugurado, em 1895, com o conto A Fada Tentadora, e que viria a tornar-se a faceta mais marcante da sua obra.

Com efeito, na literatura portuguesa de preferencial recepção infanto-juvenil, o caso de Virgínia de Castro e Almeida é manifestamente significativo. Basta, por exemplo, reler História de Dona Redonda e da sua Gente (1942) e Aventuras de Dona Redonda (1943), novelas juvenis precedidas por um díptico igualmente marcante, composto por Céu Aberto e Em Pleno Azul (ambas de 1907).

As duas narrativas editadas já nos anos 40 do século XX, e que, neste estudo revisitaremos, desenhadas em «ambiente que lembra o nonsense tão frequente em obras inglesas» (Rocha, 2001: 56) e «irradiando formas de humor e de fantasia» (Rocha, 2001: 63), estipulam, de certo modo, uma viragem no trabalho literário da autora, sendo, efectivamente, dois exemplares que integram o conjunto dos clássicos da nossa literatura para crianças (Gomes, 1997: 31).

Uma referência mais ou menos explícita a essa «viragem» é registada pela própria autora no Prefácio incluído em História de Dona Redonda e da sua Gente (1941), paratexto fundamental, aliás, para a dilucidação do tópico que nos propusemos problematizar neste estudo.

\footnotetext{
${ }^{7}$ Entre 1936 e 1944, Virgínia de Castro e Almeida publica «Pátria», uma colecção de narrativas de ficção histórica «que viria a configurar-se como importante instrumento da propaganda ideológica do Estado Novo.» (Gomes, 1997: 32).

${ }^{8}$ Sobre este tópico, vide Silva (2010: 123-137).
} 


\section{Ecos de Alice e Lewis Carroll em Virgínia de Castro Almeida e Manuel António Pina}

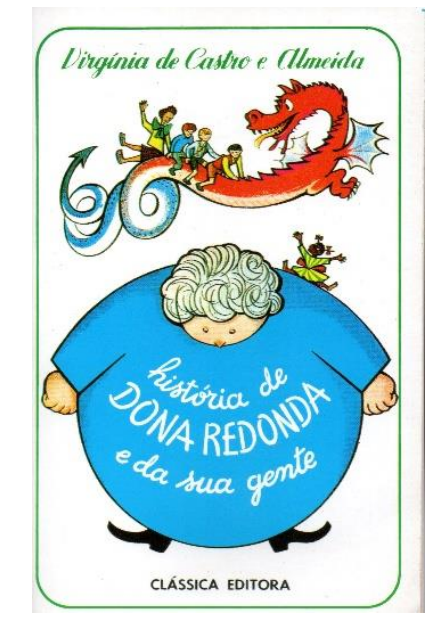

Figura 1 - Capa de História de Dona Redonda e da sua Gente (1942).

Efectivamente, neste prefácio, Virgínia de Castro e Almeida confessa abertamente a sua admiração pela obra de Carroll e identifica Alice, como acentua Lindeza Diogo, com um «Apocalipse dos pequenos» (Diogo, 1994: 100).

Pode, assim, ler-se nesse importante peritexto:

Há setenta e tantos anos um inglês chamado Charles Dodgson publicou, sob o pseudónimo de Lewis Carroll, um livro para crianças: Alice's Adventures in Wonderland. A este volume seguiu-se outro: Through the looking glass. Há talvez ingleses que não tenham lido a obra de Shakespeare, mas é bem difícil encontrar um só que desconheça as aventuras de Alice e cujos olhos se não iluminem ao ouvirem falar de Carroll.

Esta obra tornou-se a leitura clássica dos pequenos anglo-saxões há já três gerações; e nenhum de eles esquece pela vida fora os episódios de estas fantásticas e embrulhadas aventuras onde os mundos visíveis e invisíveis aparecem estreitamente ligados pelo mais subtil sense of humour, - essa tábua de salvação ou válvula de segurança do convencionalismo inglês. [...]

Alice in Wonderland e Through the looking glass são a Apocalipse dos pequenos, cuja recordação acompanha os leitores pela vida além, cuja significação mais tarde e a pouco e pouco vai surgindo. São duas torres encantadas, como a torre encantada da própria Vida, onde janelas novas se vão abrindo por magia, dissipando sombras revelando segredos, à medida que a gente sobe...

Talvez me acusem de pretender neste livro imitar Carroll. Imitar, não; graças a Deus nunca imitei ninguém. Mas confesso a minha aspiração de criar uma obra que tenha sobre os pequenos portugueses o efeito e a influência que Alice in Wonderland teve e tem sobre aqueles para quem foi escrito.

A História de Dona Redonda é um ensaio de humour ao alcance das crianças latinas; é também um ensaio de princípios tónicos, estimulantes e duros, adaptados aos tempos modernos nos quais a Vida toma imprevista feição e as lutas são já diferentes das que se pelejavam há pouco; princípios que arvoro em contraposição à moral adocicada, à goody-goodyness já dessorada e sem efeitos construtivos, mas que ordinariamente envolve e domina ainda a nossa literatura infantil.» (Almeida, 1989: X-XI).

Ainda que se possa, desde logo, assinalar uma distância entre Carroll e Castro, em concreto ao nível dos "princípios" (recorde-se que o autor de Alice deixou escrito «Posso garantir que os livros não têm absolutamente nenhum ensinamento religioso - na verdade, eles não 


\section{Sara Reis da Silva}

ensinam rigorosamente nada» e que a autora de Dona Redonda serviu o ideário estadonovista), um conjunto de similitudes entre as narrativas inglesa e portuguesa confirmam a influência sugerida e substantivam, na própria ficção, aquilo que se encontra escrito no paratexto que vimos de citar.

As narrativas de Virgínia de Castro e Almeida, protagonizadas por Dona Redonda e nas quais co-actuam, por exemplo, Dona Maluka ${ }^{9}$, Chico (um menino português), Dick (um inglês), Franz (um alemão) e Zipitri (uma menina mulata), assentam num conjunto de aventuras, quase todas pontuadas pelo maravilhoso. Nestas, convivem um cavalo alazão chamado Piki e figuras como Gil Eanes e Dick, um menino inglês, a par de Corujas, Texugos e Gatos Bravos falantes. São figuras que se movimentam em espaços físicos tão díspares como a «terra das Coisas-que-nãoexistem», a casa do infante D. Henrique, um pinhal, uma «Montanha dos Monstros», o «Palácio do Senhor Medo», a «cidade da rainha Presunção» ou uma «fortaleza encantada», entre outros. Também episódios como o da metamorfose de Dona Redonda, que se transforma em formiga ${ }^{10}$ aliás, existem várias metamorfoses nestas narrativas -, passagens como o sonho, o diálogo com a cigarra ou presença de filtros mágicos possibilitam a colocação das aventuras de Dona Redonda no espaço sussurrante do imaginário carrolliano, dando simultaneamente conta do «horizonte experimentável» (Stierle, 2008: 53) ensaiado por Virgínia de Castro e Almeida.

\section{Manuel António Pina: sobre um «gratuito e ambíguo amor pelas Alices»}

O caso de Manuel António Pina (MAP), que sempre afirmou relacionar-se relativamente bem com as suas influências («Sobretudo, estou numa de aceitação», afirma) (Pina, 2006a: 67), é talvez, e a vários títulos, como avançámos, um dos mais paradigmáticos no que respeita ao autor e à obra clássica de Carroll.

MAP alude assiduamente e com indisfarçável entusiasmo ao autor vitoriano. Diz, por exemplo, «[...] Lewis Carroll, como também, por exemplo, Edward Lear, ou A. Milne, é tudo gente das minhas relações, visitas frequentes da minha casa, que é como quem diz do meu coração. [...].» (Pina, 2005: 2). E, no prefácio à edição de O Vespão de Peruca, vindo a lume com a chancela da \&Etc., um texto intitulado «Amor Louco», confessa-se, inclusivamente, «viciado» no autor em causa ou um, entre outros, «junkies carrollianos» ${ }^{11}$, aludindo ao seu «gratuito e ambíguo amor

\footnotetext{
${ }^{9}$ Mesmo a opção por certos antropónimos, alguns bastante "bizarros", parece sinalizar a inspiração carrolliana.

${ }^{10}$ Sobre este episódio, vide Araújo, 2008.

${ }^{11}$ Recorde-se que este capítulo foi excluído intencionalmente de Alice do Outro Lado do Espelho pelo próprio Carroll.
} 


\title{
Ecos de Alice e Lewis Carroll em Virgínia de Castro Almeida e Manuel António Pina
}

pelas Alices» (Pina, 1992: 12).

José Viale Moutinho, por exemplo, numa entrevista a MAP, publicada, no dia 6 de Janeiro de 1977, no Diário de Notícias, deixa registado o seguinte comentário:

\begin{abstract}
Os outros, os críticos, esses também jogam com as palavras, falando dos livros de Manuel Pina, relacionando com os surrialistas [sic] (os maiores pagadores de favas de sempre) e com o sr. Lewis Carroll, de que este escritor português é capaz de ser primo (mesmo bastante) afastado. (Pina, 1977: 1).
\end{abstract}

Na verdade, estes "laços de parentesco" - com Carroll, mas também com vários outros autores, como se aludiu - não se pressentem apenas na sua escrita literária preferencialmente vocacionada para os mais novos, mas também nessas «filhas de Cronos, o tempo que passa, $[\ldots]$ [nesses] pobres seres insubstanciais e irrisórios, provavelmente sem sentido, provavelmente inúteis...» (Pina, 1994: 10), que são, enfim, as suas crónicas.

Espaços (im)prováveis de literatura, as Crónicas de MAP são cruzadas por referências a autores, a obras diversas e a personagens variadas. Desde Tintin e o Capitão Haddock, passando por Shakespeare e por Jonathan Swift, até Pessoa, Eugénio de Andrade, Ilse Losa ou o incomparável (para Pina) Winnie-The-Pooh (um dos livros da sua vida, como sempre afirmou), as alusões multiplicam-se e dão conta de uma escrita sobre a realidade, o «curso dos dias» (Pina, 1994: 7) e as circunstâncias que, por vezes, apenas fazem sentido se vistas à luz de um outro olhar ou de um olhar que apenas a literatura poderá ajudar a aclarar. Veja-se, a propósito, o que escreve o autor de Anacronista, a dado momento de «Antes da Crónica»:

\begin{abstract}
Outro dia caiu-me nas mãos um velho exemplar do "Diário de Notícias", também ele cheio de nomes de gente importante (ministros, deputados, militares, comerciantes), de tragédias, de "fait divers". E, todavia, o único acontecimento que, em todo o jornal, me dizia alguma coisa, umas poucas dezenas de anos depois, era uma pequena nota de duas ou três linhas numa página interior: um certo "sr. Mário de Sá-Carneiro" tinha publicado um livro de versos! Daqui a 50 ou 100 anos, o mais que algum rato de Universidade conseguirá provavelmente dizer sobre Cavaco Silva, depois de ter vasculhado em todos os arquivos, é que foi um primeiro-ministro do tempo de Eugénio de Andrade... (Pina, 1994: 10).
\end{abstract}

Alice e Carroll são também referências frequentes nesses textos modelares da obra de Pina. «Cadilhe deste lado do espelho» (idem, ibidem: 191) e «Onde se fala de Shakespeare, de Lewis Carroll e de Mota Pinto» (idem, ibidem: 197) são exemplos desse processo evocativo.

Retomando, agora, a questão que nos propusemos aflorar, Alice e Lewis Carroll ${ }^{12}$ fazem

12 MAP inclui Alice na sua lista de "eleitos", divulgada no portal do projecto Gulbenkian/Casa da Leitura (www.casadaleitura.org). Destes livros diz saber «passagens inteiras de cor». 


\section{Sara Reis da Silva}

parte do conjunto de obras e de autores que alimentam os textos (também) "para" a infância e a juventude de MAP. Nos mais de vinte livros publicados e situados habitualmente no âmbito da escrita "para" crianças e jovens, as ressonâncias de e/ou as proximidades com Alice, obra que MAP diz ter "apanhado" muito possivelmente numa ida à Biblioteca Itinerante da Gulbenkian (Pina, 2000), são perceptíveis desde o primeiro título da extensa produção literária do autor. Faremos, pois, de seguida, uma revisitação exemplificativa (e não exaustiva) de alguns textos e/ou segmentos verbais (e também icónicos) nos quais se pressentem as influências em questão.

Obra inaugural do universo literário que MAP, desde $1973^{13}$, destinou ao receptor infantil (mas não apenas), O País das Pessoas de Pernas para o Ar é composta por quatro contos: «O país das pessoas de pernas para o ar», «A vida de um peixinho vermelho», «O menino Jesus não quer ser Deus» e «O bolo e o menino Jesus».

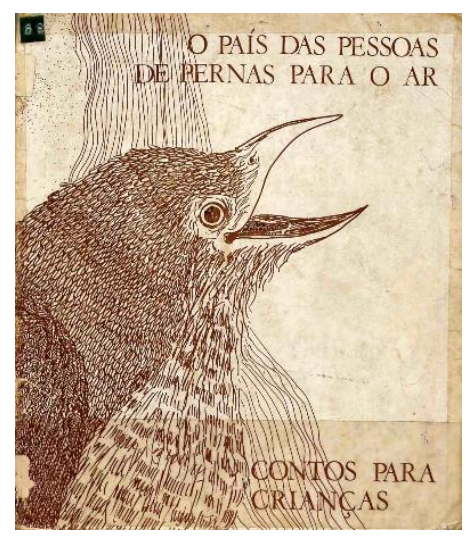

Figura 2 - Capa de O País das Pessoas de Pernas para o Ar (1973).

Esta colectânea, que corresponde ao primeiro título da colecção «Lobo Bom» ${ }^{14}$ da extinta editora A Regra do Jogo ${ }^{15}$, é ilustrada por João / João B., ou seja, João Botelho, também responsável pela componente visual de outras obras de MAP.

É talvez no segundo conto desta obra, «A vida dum peixe vermelho», que, com mais nitidez, se detecta um diálogo intertextual, de raiz endoliterária e a exigir do leitor uma abrangente competência literária, designadamente pelas ligações que se pressentem entre este texto e Aventuras de Alice no País das Maravilhas e Alice do Outro Lado do Espelho.

\footnotetext{
${ }^{13} \mathrm{Na}$ edição de $O$ País das Pessoas de Pernas para o Ar a que tivemos primeiramente acesso encontra-se o registo «Porto, 18 de Dezembro de 1973».

${ }^{14}$ Desta colecção fazem parte: 1. O País das Pessoas de Penas para o Ar (MAP e João Botelho, Dezembro de 1973); 2. Gigões \& Anantes (MAP e João Botelho, Dezembro de 1974); 3. Joanica - Puff (A. A. Milne, Dezembro de 1974). Esta referência reveste-se, em nosso entender, de uma relativa importância, se atendermos às ligações da obra de MAP ao texto de Milne. Recorde-se que, em 2006, o autor de $O$ Inventão publica o ensaio «Winnie-the-Pooh, breve notícia» (Pina, 2006b) e, já em 2009, na revista Notícias Magazine, a crónica «F de Falso» (Pina, 2009).

${ }^{15}$ Esta editora portuense foi fundada em 1973 e pertenceu ao editor e livreiro José Leal Loureiro, amigo de MAP e de João Botelho.
} 


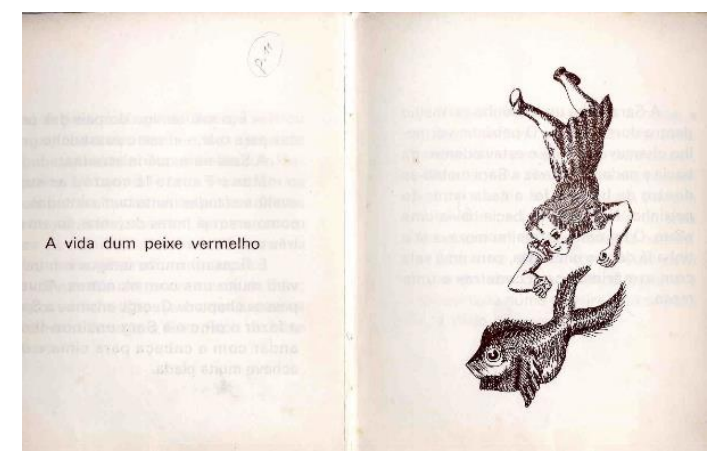

Figura 3 - Abertura do conto «A vida de um peixe vermelho».

A orientar, de modo mais ou menos explícito, a leitura para este sentido, encontramos, em primeiro lugar, a ilustração que acompanha o título, uma representação de uma figura infantil feminina e de um peixe, que segue de perto ou parece aludir ${ }^{16}$ à linguagem pictórica de John Tenniel (1820-1914), artista vitoriano que ilustrou a edição de $1865^{17}$ das duas Alices. Em segundo lugar, importa juntar-se, ainda, a este aspecto icónico a referência final a «Alice Lidell», ou seja e como se sabe, a menina de dez anos, a quem, acompanhada das suas duas irmãs, o autor contou uma primeira história, originalmente As Aventuras de Alice debaixo da Terra, durante um passeio de barco no Tamisa, em 4 Julho de 1862.

Mas a ligação entre o texto de MAP e os de L. Carroll plasma-se, ainda, nos importantes episódios do conto coincidentes com o movimento descendente ${ }^{18}$ de Sara, até ao

\footnotetext{
${ }^{16}$ Assumimos aqui como alusão o tipo de prática intertextual que corresponde, tendo em conta os tipos de intertextualidade destacados por G. Genette, e conforme esclarece o Diccionario de Termos Literarios da Equipo Glifo, à relação de co-presença menos literal entre vários textos, sendo própria dos enunciados que, para a sua total compreensão, exigem o reconhecimento de uma conexão implícita com outro ou outros enunciados, que não se encontram incluídos como tal no primeiro enunciado (Glifo, 1998/2003: 79). Segundo K. Stierle, a alusão é também «uma forma de saber cultural que não põe efectivamente em jogo um outro (pre)texto, mas sim a recordação dele. Na relação intertextual da alusão, é revelada a presença de espírito do aludente, que põe à prova o saber literário ao seu dispor e a capacidade de o utilizar frutuosamente e de o trazer para uma relação expressiva com a continuidade objectiva que está na origem do discurso presente.» (Stierle, 2008: 62).

${ }^{17}$ Note-se que os primeiros desenhos de Alice foram efectuados pelo próprio L. Carroll: «The story was not, in fact, completed in fair copy until the New Year, while the drawings which Dodgson had decided do provide [...] took even longer; in March 1863 he borrowed a book of natural history from the Deanery to help get the pictures of some animals right. Moreover by this time the project had ceased to be simply a gift-book for Alice. [...] By January 1864 Dodgson had decided that he needed a professional illustrator. Tom Taylor [...] introduced him to one of his magazine's most accomplished cartoonists, John Tenniel, who, after reading Dodgson's manuscript, agreed to illustrate the book.» (Carpenter e Prichard, 2005: 16-17).

${ }^{18} \mathrm{Cf}$., por exemplo, «[...] correu pelos campos atrás dele [do Coelho], mesmo a tempo de o ver enfiar-se por uma enorme toca debaixo de uma sebe. Num instante, Alice enfiou-se também atrás dele, sem pensar sequer como diabo é que havia de sair outra vez. A toca continuou a direito como um túnel, e de repente afundou-se, tão de repente que a menina nem teve tempo de reflectir e parar antes de dar consigo a descer o que lhe parecia ser um poço muito fundo. [...] A descer, a descer, sempre a descer. [...] A descer, a descer, sempre a descer.» (Carroll, 2000: 9-11).
} 


\section{Sara Reis da Silva}

fundo de uma bacia, com a transposição de uma porta ${ }^{19}$ para ingressar em outro espaço e com a própria "viagem aquática" ${ }^{20}$. Em qualquer dos casos, à semelhança do que sucede em Alice, observa-se uma manipulação do espaço e do tempo e, consequentemente, um desvio da sua apresentação convencional.

Os aspectos enunciados substantivam, igualmente, alguns dos sentidos simbólicos que, em nosso entender, acabam por pontuar um e outro texto. Com efeito, a descida pode representar, tanto para Sara, como para Alice, uma dissipação do mundo exterior (Chevalier e Gheebrant, 1994: 623), do factual ou real empírico, acessível através da porta, enquanto «lugar de passagem entre dois estados, entre dois mundos, entre o conhecido e o desconhecido» (Chevalier e Gheebrant, 1994: 537), como meio de ingresso numa atmosfera distinta ou, ainda, de contacto com outras pessoas/seres. Além disso, na linha do que preconiza Jean Webb, em relação a Alice, no ensaio «Alice as subject in the logic of Wonderland» (Webb, 2002: 63-69), o percurso descendente de Sara, a sua ligação afectiva com o peixinho vermelho e, em especial, a aceitação inevitável da sua morte podem ser lidos, ainda, enquanto etapas do seu crescimento, da sua maturação psicoafectiva e/ou de autoconhecimento.

Acresce, ainda, como aludimos, a presença de uma ilustração, colocada logo após o título, com evidentes afinidades com o discurso pictórico de J. Tenniel. O segmento visual em causa é composto apenas pela figura de uma menina e de um peixe e a sua representação cria a ilusão de um movimento descendente. Seguindo o modelo de J. Tenniel, a imagem da menina criada por João Botelho assemelha-se a uma «menina de verdade» (Obiols Suari, 2004: 32), construída a partir de uma «matéria visual representacional próxima do realismo» (Obiols Suari, 2004: 33), ainda que, no caso concreto do livro de MAP, este aspecto ocorra apenas parcialmente.

Um ano após a edição de $O$ País das Pessoas de Pernas para o Ar, veio lume Gigões \& Anantes (1974) (reed. - 1977).

\footnotetext{
${ }^{19} \mathrm{Cf}$., por exemplo, «Havia muitas portas em redor do átrio, mas estavam todas trancadas. [...] De repente, viu à frente dos olhos uma pequena mesa de três pernas, toda em vidro maciço; em cima dela havia apenas uma pequena chave dourada, e o primeiro pensamento de Alice foi que devia pertencer a uma das portas do átrio. Mas não: ou eram as fechaduras que eram muito largas, ou a chave que era muito pequena - fosse como fosse, não conseguia abrir nenhuma. Contudo, da segunda vez que deu a volta, achou uma pequena cortina em que não reparara antes, e atrás dela estava uma pequena porta de cerca de trinta centímetros de altura: tentou enfiar a chave dourada na fechadura e, para seu grande contentamento, servia! Alice abriu a porta e descobriu que dava para um pequeno corredor [...].» (Carroll, 2000:13-14).

${ }^{20}$ Cf., por exemplo, «[...] o pé escorregou-lhe, e, no instante seguinte, trás! Mergulhou em água salgada até ao pescoço. A primeira ideia que lhe assomou o espírito foi que caíra misteriosamente ao mar [...] Contudo, depressa se apercebeu de que estava no lago de lágrimas que chorara quando tinha três metros de altura.» (Carroll, 2000: 25).
} 
Ecos de Alice e Lewis Carroll em Virgínia de Castro Almeida e Manuel António Pina

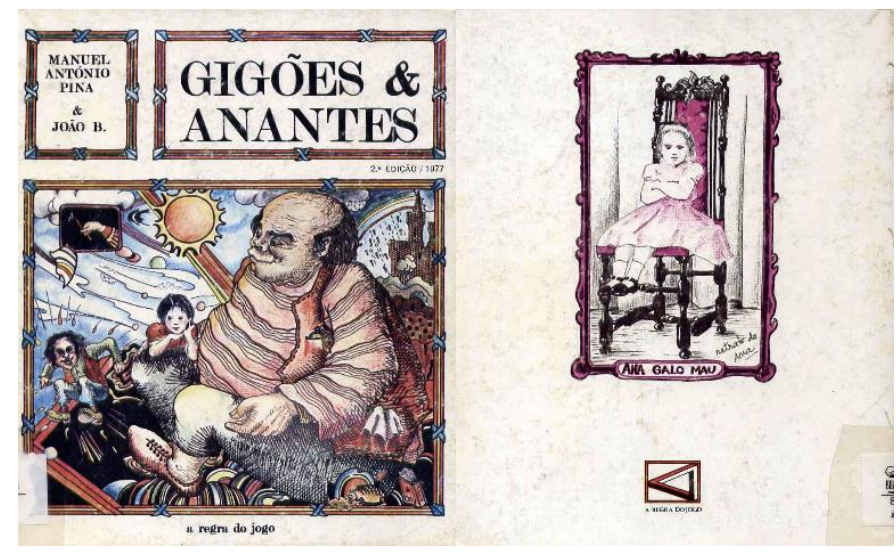

Figuras 4 e 5 - Capa e contracapa de Gigões \& Anantes (1974).

Constituindo o n. ${ }^{\circ} 2$ da já referida colecção «Lobo Bom» da A Regra do Jogo, a obra Gigões \& Anantes engloba quatro textos: «Gigões \& Anantes» - que dá título à colectânea -, «Para baixo e para cima», «Conversa com um escaravelho» e «Abdulum \& Abduldois». Posteriormente, todos estes textos ressurgem integrados em O Têpluquê e outras histórias (1995).

$\mathrm{Na}$ capa de Gigões \& Anantes, observa-se uma associação insólita de elementos que decorre, por exemplo, do jogo de proporções ou da co-presença de motivos visuais muito diversos do ponto de vista dimensional, colocados num cenário com uma configuração próxima do maravilhoso / fantástico. Aparentemente, este quadro visual integra as figuras fundamentais dos textos que compõem a obra: uma personagem feminina infantil, no texto, com o nome Ana; um gigante/gigão; um anão/anante; um escaravelho. A inclusão subtil - no canto inferior direito - de um pequeno livro, colocado de "pernas para o ar" e no qual se pode ler a inscrição «Alice», poderá indiciar a entrada no mundo contrafactual que os textos literários recriam. Além disso, a referida inscrição vocabular onomástica permite, se aceitarmos as possibilidades de leitura intertextual que esta abre, a criação de expectativas ao nível ideotemático e, até, no que diz respeito às estratégias ou aos recursos que sustentam o processo criativo dos textos contidos em Gigões \& Anantes. Referimo-nos, por exemplo, à técnica da inversão e ao humor, decorrente, em larga medida, do nonsense e do absurdo, e, mesmo, ao tópico do "mundo às avessas" ou do desconcerto do mundo que, com efeito, acabam por dominar a narrativa clássica de L. Carroll, texto aqui indirectamente evocado. Com efeito, como regista Jorge Listopad, a prevalência do nonsense ou de um universo ficcional dominado pelo «absurdo gentil» inscreve Gigões \& Anantes «no território da Alice de Lewis Carroll» (Listopad, 1975: 80).

Também o título da narrativa «Abdulum \& Abduldois», encerrando, uma vez mais, um exercício criativo de índole neológica, a partir do recurso à aglutinação de um nome próprio - 


\section{Sara Reis da Silva}

Abdul - e de dois algarismos (numerais cardinais), poderá ser aproximado, em parte, do jogo onomástico que se constata no capítulo «Tuidledum e Tuidledim» de Alice Do Outro Lado do Espelho.

Refira-se, ainda, que a página que antecede este conto e na qual se regista o seu título, se destaca pela originalidade da componente ilustrativa. A esta espécie de frontispício, segue-se um tríptico, composto por três "quadros" emoldurados ou por um painel (central), ladeado por dois postigos ou volantes. O painel é dominado pela representação de uma figura infantil feminina, de braços cruzados, sentada numa cadeira pomposa, de formato clássico. Esta imagem é verbalmente identificada através do segmento "retrato de Ana" e, ainda, por um outro, de aparência absurda, «Ana Galo Mau», que pode, aliás, ser lido como o título genérico da ilustração tripartida que preenche a página em análise. Importa desvendar a origem desta "legenda". Com efeito, esta expressão, conforme informalmente nos revelou MAP, é uma espécie de homenagem («tortuosíssima e quase privada», como sublinhou) a Alice no País das Maravilhas. «Ana Galo Mau» é a tradução literal de Anne Badcock, o modelo que serviu a John Tenniel para as ilustrações da obra de Carroll.

Também no texto dramático Perguntem aos Vossos Gatos e aos Vossos Cães... (2002), uma versão expandida e ligeiramente alterada de Os 2 Ladrões (1983), é possível identificar algumas ressonâncias do texto Carrolliano.

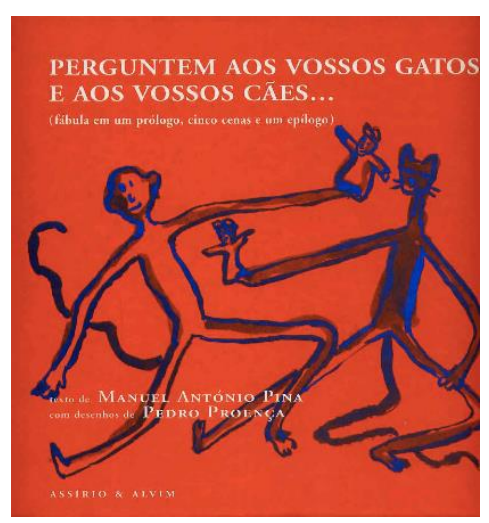

Figura 6 - Capa de Perguntem aos Vossos Gatos e aos vossos Cães... (2002).

A acção central de Perguntem aos vossos Gatos e aos vossos Cães..., composta por cinco cenas intituladas «I - O Reino Animal», «II - Os Dois Ladrões», «III - Entregues à Bicharada», «IV - O Tribunal do Elefante» e «V - O Tribunal dos Espectadores», situa-se «numa terra distante» / (Deus nos livre que fosse aqui!)» (Pina, 2002: 11).

Globalmente, MAP, encenando uma situação humorística, na qual é fundamental a recriação de uma terra longínqua e geograficamente indeterminada, onde quem manda são os 


\section{Ecos de Alice e Lewis Carroll em Virgínia de Castro Almeida e Manuel António Pina}

bichos, sendo os homens seus animais de estimação ${ }^{21}$, quase todos prisioneiros "por vontade", ficcionaliza, de forma criativa, um universo dominado pela transposição ${ }^{22}$, bem como pelo tópico maneirista do mundo às avessas ou pela recorrente linha temática do desconcerto do mundo. É, assim, virando "o mundo de pernas para o ar" que Pina, assumindo uma atitude simultaneamente lúdica, crítica e irreverente, parece querer denunciar alguns dos seus defeitos, abalando essa espécie de "status quo", que impede que alguns seres humanos / certos animais sejam livres ou mudem de condição.

Desta peça destacamos a cena do «julgamento invulgar» (Pina, 2002: 21) dos dois Ladrões sem nome, «dois seres humanos normais / vivendo entre animais!» (Pina, 2002: 12), que foram apanhados a roubar a chave da porta da Liberdade. Este segmento afigura-se, em tudo, anedótico ou desconcertante, pois joga, defraudando-as, com as expectativas do receptor ${ }^{23}$, visto que, neste, um Papagaio advogado de acusação é indigitado também de defesa, um Juiz Elefante abre a audiência e espera «fechá-la depressa», pois está com pouca paciência!» (Pina, 2002: 24), já tendo a sentença feita e dizendo dela não se desviar «aconteça o que acontecer» (Pina, 2002: 24), aos dois réus não é concedido tempo de dizer nada em sua legítima defesa ${ }^{24}$ e, no final, a sentença é surpreendentemente ${ }^{25}$ paradoxal:

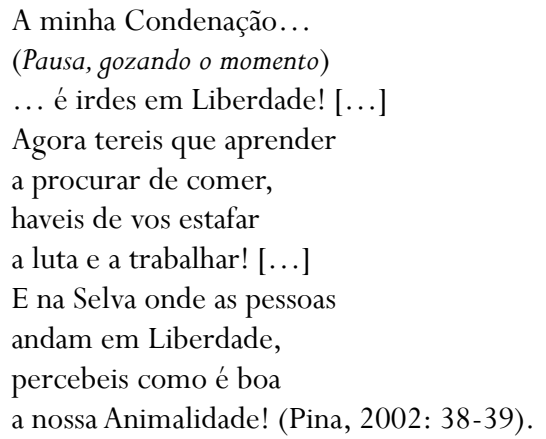

\footnotetext{
${ }^{21}$ Este quadro ficcional pode relacionar-se, do ponto de vista intertextual, com o célebre episódio do país dos cavalos com raciocínio, que possuem, na sua dependência, uma espécie humana decadente, um episódio contido em AsViagens de Gulliver (obra originalmente publicada em $1726 \mathrm{com}$ o título Travels into several Remote Nations of the World. Lemuel Gulliver, first a surgeon, and then a captain of several ships), do irlandês J. Swift (1667-1745).

${ }^{22}$ Cf. «A transposição, a mudança de ambiente é uma condição essencial favorável à paródia.» (Zervou, 2000: 32 ).

${ }^{23} \mathrm{Cf}$. «[...] a importância da questão do conhecimento partilhado entre o emissor e o receptor da mensagem humorística é fundamental.» (Ermida, 2003: 219).

${ }^{24}$ Cf. «ELEFANTE [...] Oh, Diabo, já me ia a esquecer! / Tendes alguma coisa a dizer? / Não é que sirva para nada, / mas a Lei tem de ser respeitada! // PRIMEIRO LADRÃO (Titubeante) Eu queria dizer que... / SEGUNDO LADRÃO / ... e eu também... / ELEFANTE (Interrompendo-os) Pronto, já dissestes!» (Pina, 2002: 34-35). (N.B. Seguimos, nas transcrições, a configuração dos caracteres da edição citada - nomes das personagens registadas em letras maiúsculas).

${ }^{25}$ A este propósito, ressalte-se que I. Ermida, no estudo «Nas entrelinhas do riso: pressuposições semânticas e pragmáticas no discurso cómico», sublinha que é «consensual entre os teóricos do humor que a surpresa deve ocorrer para despoletar o prazer cómico» (Ermida, 2005: 68).
} 


\section{Sara Reis da Silva}

Este e outros segmentos de Perguntem aos Vossos Gatos e aos Vossos Cães... aproximam-se do episódio (capítulo XI) intitulado «Quem roubou as tartes?», de Aventuras de Alice no País das Maravilhas. Na verdade, também aqui, se nota, por exemplo, a ignorância dos trâmites legais (o Rei sabe muito pouco), a injustiça e o despotismo.

No texto de MAP, como no de L. Carroll, é fundamental a configuração cómica do discurso, e, neste âmbito, ressalte-se a importância da estratégia da transposição, «enquanto condição essencial favorável à paródia» (Zervou, 2000: 32). A ironia, a apropriação recriativa de expressões idiomáticas e/ou populares (no caso da peça de MAP) e os equívocos sustentam também a vertente humorística deste texto.

$\mathrm{Na}$ linha do que preconiza Zohar Shavit (2003), quando lê Aventuras de Alice no País das Maravilhas como texto ambivalente, também MAP combinou dois modelos relevantes da literatura para a infância - o da história de aventuras e o da história de fantasia -, juntando-lhes ainda um outro, o da história de absurdo. Ainda sob o cinzentismo do Estado Novo, MAP rompe, pois, com as "normas" dominantes na literatura portuguesa para crianças, vem a servir de inspiração ou de modelo para outros autores e para outros livros e ficará sempre "do outro lado", não apenas de Alice e de Carroll, ou de tantos outros livros e autores, mas do lado daqueles que sentem prazer em «tentar ver as coisas do outro lado», insistindo em «ver as coisas de outra maneira», «como quem, ainda/quando criança, abre um relógio» (Pina, 2006b: 58).

\section{Considerações finais}

Concluímos, reafirmando que, quer na obra de Virgínia de Castro e Almeida, quer na de Manuel António Pina, no caso da deste último, com muito maior incidência e consistência (como prova a demorada atenção que aos seus textos concedemos), são muitos os episódios pontuados pela inverosimilhança, pelo maravilhoso ou pelo fantástico, pelo humor, pelo nonsense e por uma especial ludicidade, aspectos que testemunham o legado carrolliano na escrita destes dois autores. As fortes ligações intertextuais, mais ou menos reconhecíveis, que se pressentem nos textos dos autores portugueses seleccionados à obra de Carroll constituem um espaço fértil de cruzamento literário que inquieta e estimula leitores com distintas competências literárias, além de atestarem a pervivência de um clássico universal protagonizado por Alice. Note-se que, por exemplo, no caso concreto de MAP, a matriz não se restringe ao texto narrativo, ao discurso literário, mas estende- 
Ecos de Alice e Lewis Carroll em Virgínia de Castro Almeida e Manuel António Pina se à própria composição visual original da narrativa canónica em questão.

Certamente que regressos como o que concretizámos neste estudo a Alice no País das Maravilhas, bem com a sua revisitação assídua, em forma criativa ou hermenêutica, representam uma garantia de que $\ll[\ldots]$ as aventuras dessa Alice eterna manifestar-se-ão numa outra narrativa...» (Cláudio, 2015: 19), em muitas outras escritas.

\section{Referências bibliográficas:}

Almeida, V. de C. e (1989). História de Dona Redonda e da sua Gente. Lisboa: Clássica Editora (6ª ed.; $1^{a}$ ed. - 1942).

Almeida, V. de C. e (1990). Aventuras de Dona Redonda. Lisboa: Clássica Editora (5a ed.; $1^{\mathrm{a}}$ ed. 1943).

Araújo, M. A. T. (2008). A Emancipação da Literatura Infantil. Porto: Campo das Letras.

Bache-Wiig, H. (2006). “Philosophical Homework or Universal Amazement? Jostein Gaarder's Sophie's World". En Beckett, Sandra L. and Nikolajeva, Maria (Ed.). Beyond Babar. The European Tradition in Children's Literature (pp. 255-276). Lanham/ Toronto/Oxford: The Scarecrow Press.

Bakhtine, M. (1984). Esthétique de la création verbale. Paris: Gallimard.

Barthes, R. (1984). Le bruissement de la langue. Paris: Seuil.

Carpenter, H. and Prichard, M. (2005). The Oxford Companion to Children's Literature. Oxford: Oxford University Press (1 $1^{\text {a }}$ ed. 1984).

Carroll, L. (2000). As Aventuras de Alice no País das Maravilhas e Alice do Outro Lado do Espelho. Relógio d'Água (ilustrações de John Tenniel).

Chevalier, J. e Gheerbrant, A. (1994). Dicionário de Símbolos. Lisboa: Teorema.

Diogo, A. A. L. (1994). Literatura Infantil. História. Teoria, Interpretaçôes. Porto: Porto Editora.

Equipo Glifo (1998). Diccionario de Termos Literarios - Vol. e-h. Santiago de Compostela: Xunta de Galicia/Centro Rámon Piñeiro para a Investigación en Humanidades.

Ermida, I. (2003). Humor, Linguagem e Narrativa. Para uma Análise do Discurso Literário Cómico. Braga: $\mathrm{CEH} /$ Universidade do Minho.

Ermida, Isabel (2005). "Nas entrelinhas do riso: pressuposições semânticas e pragmáticas no discurso cómico". En Marques, Mª Aldina, Koller, Erwin, et ali (Ed.). Ciências da 


\section{Sara Reis da Silva}

Linguagem: 30 anos de investigação e ensino (pp. 67-83). Braga: ILCH/Centro de Estudos Humanísticos/Universidade do Minho.

Gomes, J. A. (1997). Para uma História da Literatura Portuguesa para a Infância e a Juventude. Lisboa: Ministério da Cultura/Instituto Português do Livro e das Bibliotecas.

Gomes, J. A. (1999). “Carroll's Adventures in Portugal”. Fragmentos, 16, jan - jun/ 1999, Florianópolis, 127-133.

Kristeva, J. (1974). La revolution du langage poétique. Paris: Seuil.

Lemos, E. de (1972). A Literatura Infantil em Portugal. Lisboa: Ministério da Educação Nacional.

Lerer, S. (2009). La Magia de Los Libros Infantiles. Barcelona: AresY Mares.

Listopad, J. (1975). "Recensão crítica a Gigões \& Anantes e outras histórias". Colóquio/Letras, 27, Setembro de 1975, 80 .

Machado, A. M. (2002). Como e Por Que Ler os Clássicos Universais desde Cedo. Rio de Janeiro: Objetiva.

Obiols Suari, N. (2004). Mirando Cuentos. Lo visible e invisible en las ilustraciones de la literatura infantil. Barcelona: Laertes.

Pina, M. A. (1973). O País das Pessoas de Pernas para o Ar. Porto: A Regra do Jogo (ilustrações de João Botelho).

Pina, M. A. (1974). Gigões \&Anantes. Porto: A Regra do Jogo (ilustrações de João Botelho).

Pina, M. A. (1977). “Quem escreve tem necessariamente de o fazer para alguém?” (entrevista conduzida por José Viale Moutinho). Diário de Notícias ( $2^{\circ}$ Caderno), 06 de Janeiro de 1977, Suplemento Cultural, 1.

Pina, M. A. (1992). “Amor Louco” prefácio a Carroll, Lewis. O Vespão de Peruca (pp. 5-12). Lisboa: \&Etc.

Pina, M. A. (1994). O Anacronista. Porto: Afrontamento.

Pina, M. A. (2000). "Escrevo. Acho eu, para mim, isto é, para outros" (entrevista por José António Gomes). Malasartes [Cadernos de Literatura para a infância e a Juventude], 2 (Abril de 2000), 3-5.

Pina, M. A. (2002). Perguntem aos Vossos Gatos e as Vossos Cães.... Lisboa: Assírio \& Alvim (ilustrações de Pedro Proença).

Pina, M. A. (2005). "Entrevista a Manuel António Pina”. Critério (Revista de Expressão e Cultura dos Estudantes de Direito da UCP), 1 - Outubro de 2005, 4-6. 
Ecos de Alice e Lewis Carroll em Virgínia de Castro Almeida e Manuel António Pina

Pina, M. A. (2006a). "Manuel António Pina - O Refúgio da Poesia" (entrevista por Carlos Vaz Marques). Ler, 68, Junho de 2006, 50-69.

Pina, M. A. (2006b). "Winnie-the-Pooh, breve notícia” (ensaio). Águas Furtadas, 10 (Literatura, Música e Artes Visuais) - Outubro de 2006. Porto: NJAP/JU - Núcleo de Jornalismo Académico do Porto/Jornal Universitário, 98-122 (texto correspondente à intervenção lida na Culturgest, em 10/02/03 (Lisboa) e em 15/02/03 (Porto), integrada no ciclo de conferências "Clássicos do Século XX”).

Pina, M. A. (2009). “F de Falso”. Notícias Magazine, 31 de Maio de 2009, 96.

Pina, M. A. (2010). Por Outras Palavras \& mais crónicas de jornal. Porto: Modo de Ler.

Pires, M. L. B. (1983). História da Literatura Infantil Portuguesa. Lisboa: Vega.

Riffaterre, M. (1979). La production du texte. Paris: Seuil.

Shavit, Z. (2003). Poética da Literatura para Crianças. Lisboa: Caminho.

Rocha, N. (1984/2001). Breve História da Literatura para Crianças em Portugal. Lisboa: ICALP/Editorial Caminho.

Silva, V. A. e (1990). Teoria da Literatura. Coimbra: Almedina ( $8^{a}$ ed.).

Silva, S. R. (2010). "Between open adventure in foreign lands and confined living in Portugal: Portuguese children's literature and the work of Virgínia de Castro e Almeida”. AILIJ (Anuario de Investigación en Literatura Infantil y Juvenil), 8 (1), 123-137.

Silva, S. R. (2013). Presença e Significado de Manuel António Pina na Literatura Portuguesa para a Infância e a Juventude. Lisboa: Fundação Calouste Gulbenkian/Fundação para a Ciência e a Tecnologia.

Stierle, K. (2008). “Obra e intertextualidade”. Existe uma Linguagem Poética? Seguido de Obra e Intertextualidade (pp. 39-65). Vila Nova de Famalicão: Edições Quasi.

Vasconcelos, H. (2009). A Infância é Um Território Desconhecido. Lisboa: Quetzal.

Webb, J. (2002). "Alice as subject in the logic of Wonderland". En Thacker, Deborah Cogan \& Webb, Jean (Eds.) Introducing Children's Literature. From Romanticism to Postmodernism (pp. 6369). London/New York.

Zervou, A. (2000). "Le comique e(s)t le parodique dans la littérature d'enfance". En Perrot, Jean (2000) (Ed.). L'humour dans la littérature de jeunesse (pp. 29-44). Col. «Lectures d'enfance», Paris: IN PRESS. 
Sara Reis da Silva 